\title{
THE MUSCLE OF BIRD FLIGHT: STRUCTURE AND FUNCTION
}

BENJAMIN W.C. ROSSER, Department of Anatomy, University of Maryland, Baltimore, Maryland, U.S.A. 21201

A Turkey Vulture soars in the slimmer sky, high above the Qu'Appelle Valley. Its outstretched wings are held almost motionless against the air currents rising from below. A Canada Goose, by comparison, will beat its wings 3-5 times/second while flying $2000 \mathrm{~km}$ from northern Missouri to the Hudson Bay Lowlands. After this journey of over half a million (estimated) wing beats, female geese will obtain protein for the formation of eggs from the atrophy of their major flight muscles. House Sparrows tumble over one another for a crust of bread in subzero Edmonton. The biochemistry of their muscles has been altered to generate more heat during the winter. Primarily one muscle, the pectoralis (breast muscle), is responsible for these varied activities. In each case, the muscle is uniquely adapted to meet the demands of the environment.

\section{Pectoralis Muscle}

The pectoralis muscle of birds can function in locomotion, protein storage and heat generation. This muscle is a massive organ which, depending upon the species, can comprise from 7 to $27 \%$ of the fresh body weight of a bird. ${ }^{6}$ The pectoralis is present as separate left and right halves (Fig. 1). Each half arises mainly from the keel of the breast bone (sternum), and attaches to the shoulder (humerus) of its respective wing. The muscle provides virtually all of the power for the downstroke of the wing, which is necessary to provide the lift for flapping flight. ${ }^{10}$

\section{Muscle Fibers}

Countless thousands of muscle fibers make up the avian pectoralis. Muscle fibers are the microscopic, cylindrical contractile cells of which all striated muscles are composed. There are several types of muscle fibers. ${ }^{7}$ Certain types are specialized for rapid, repeated contraction, and others for slow, individually prolonged contractions. These types are termed fast and slow, respectively. Fast fibers are further differentiated into red, white and intermediate types. Red fibers are comparatively small in diameter, and are specialized for sustained rapid activity. White fibers have larger diameters, and are specialized for brief, powerful bursts of activity. Intermediate fibers are between red and white fibers in their properties and characteristics.

The differences between red and white fibers are biochemical in origin. ${ }^{5}$ Muscle contraction requires energy, which is obtained primarily from two "fuels:" fat and glycogen. Red fibers derive their energy mainly by the metabolism of fat in the presence of oxygen. White fibers use glycogen in the absence of oxygen. Fat is the more efficient fuel, but glycogen can supply energy more quickly.

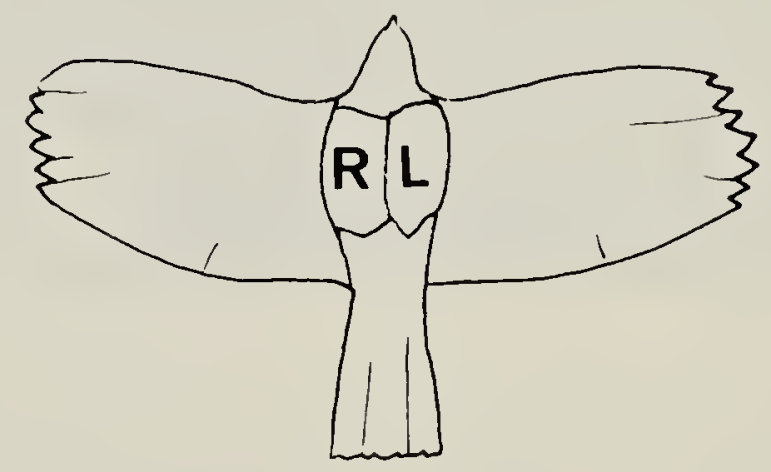

Figure 1. Ventral view of the left $(L)$ and right $(R)$ pectoralis muscles of a typical bird. 
Glycogen is also rapidly transformed into waste products which inhibit muscle contraction. Consequently, white fibers contract rapidly at first but soon fatigue. The smaller diameter of the red fibers facilitates the diffusion of oxygen into the cells. Also, a difference in colour between red and white fibers is due to the presence of myoglobin (a protein for the transport and storage of oxygen). Red fibers contain much myoglobin and, as a result are dark red in colour; white fibers have little myoglobin and are lightcoloured. Muscle fibers impart their colour to the muscle as a whole. The familiar dark meat and light meat of a turkey dinner are largely due to a preponderance of red or white fiber types in the muscles. There are also biochemical differences between fast (red, white and intermediate) and slow fibers; though these differences are in the cell membranes and contractile proteins. 910

Locomotion: Structure correlates with function

The mode of flight exhibited by any species of bird is related to the type of muscle fibers found in the pectoralis. Flapping flight requires rapid, repeated contractions of the pectoralis muscle. The muscle consists exclusively (99-100\%) of fast fiber types in all of those species studied which employ flapping flight. ${ }^{14}$ Slow fibers do occur in relatively large numbers, however, in the pectoralis of those birds most adept at soaring flight, such as the Turkey vulture. ${ }^{15}$ These fibers are apparently used for maintaining the wings in an outstretched position against wind resistance. Slow prolonged contractions are well suited to such a function. Some slow fibers also occur in the pectoralis of the Ostrich, Emu and Kiwi. ${ }^{3}$ This may be a result of flightlessness in these birds, and underscores the demands that flapping flight places upon the muscles.

Birds such as the Ruffed Grouse, which are specialized for explosive flight of short duration, have a pectoralis muscle consisting almost entirely of white and intermediate fiber types (Fig. 2). The pectoralis of these species appears whitish, as it does in the Domestic Chicken. The muscle, however, consists mainly of red fibers in most species (see Table 1.), and is dark red in colour due to the high myoglobin content. The Domestic Pigeon, for example, has red and white fibers (Fig. 3), and the Yellow-headed Blackbird red and intermediate fiber types (Fig. 4). The muscle consists entirely of red fibers in most small passerines, such as the Red Crossbill (Fig. 5).

\section{Table 1. EXAMPLES OF FIBER TYPES IN THE AVIAN PECTORALIS MUSCLE.}

Species

Rufted Grouse

Great Horned Owl

Mallard

Domestic Pigeon

Northern Harrier

European Starling

Black-capped Chickadee

House Sparrow
Fiber Type*

WIR

IR

RW

RW

RI

RI

R

R

$W=$ white, $I=$ intermediate, $R=$ red .

Fiber types are listed in order of decreasing proportion. ${ }^{14}$ 


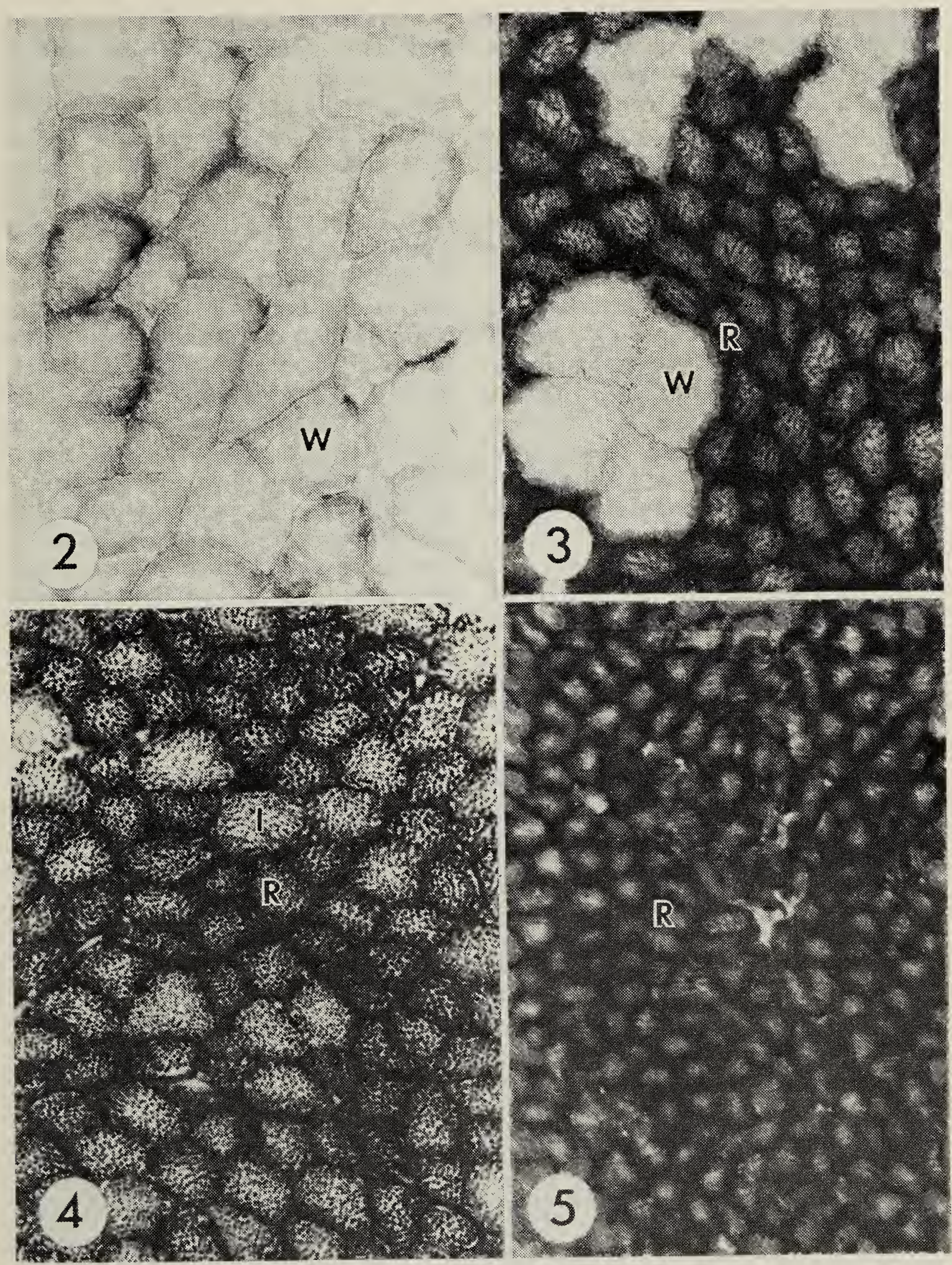

Figures 2-5. Cross sections of muscle fibers from the pectoralis muscle of a Ruffed Grouse (Fig. 2), Domestic Pigeon (Fig. 3), Yellow-headed Blackbird (Fig. 4) and Red Crossbill (Fig. 5). Muscle fibers have been stained for succinate dehydrogenase (SDH) activity. " SDH is a key enzyme used to metabolize "fuels" (mainly fat) in the presence of oxygen. $W=$ white, $I=$ intermediate, $R=$ red fibers. Magnification 420X. 
Take-off is the phase of flight requiring the most power, and large birds have higher power requirements for flight than do smaller birds. ${ }^{10}$ Consequently, large)bodied birds capable of rapid, near vertical take-offs, such as herons, geese and dabbling ducks, have a large number of white fibers in their predominantly red pectoralis muscle. These white fibers are undoubtedly used during take-off and other periods of intense activity. Red fibers are sufficient for meeting all of the power requirement of most small birds. Nevertheless, certain small birds, such as shorebirds, are capable of extremely rapid takeoff and ascent. These birds have large numbers of white and/or intermediate fibers in the muscle.

\section{Thermogenesis: heat production}

Birds produce heat by shivering when exposed to cold, and as shivering is muscular contraction, the comparatively massive pectoralis plays a major role. ${ }^{4}$ Small passerines, such as the Blackcapped Chickadee, are able to sustain shivering for longer periods in the winter than in the summer. ${ }^{3}$ While glycogen may initially be used for short periods of shivering, winter birds are better able to utilize fat, and fat is the preferred fuel for shivering during this season. Prolonged exposure to cold results in a decrease in the diameter of the red fibers in the pigeon pectoralis, presumably to increase the capacity for fat utilization. It has also been suggested that an alteration of the biochemical pathways may permit the pectoralis muscle of birds to produce heat by nonshivering thermogenesis, still utilizing fat as fuel. ${ }^{4}$

\section{Protein Reserve}

Muscles contain large amounts of protein, which can be mobilized during periods of dietary protein deficiency. A muscle not in use will atrophy, and the protein within it can be transported to other regions of the body and used for other purposes. The females of many. species use the protein of the pectoralis muscle for egg formation. This is especially pronounced in northern nesting geese, which begin egg formation before the snow cover has melted and before dietary protein becomes available. ${ }^{12}$ Also, during moult, many species of waterfowl have a simultaneous loss of the flight feathers. This renders these birds flightless, with a concomitant loss of protein from the pectoralis. Some of this protein may be used for the growth of the new flight feathers and/or the hypertrophy (enlargement) of the leg muscles. ${ }^{12}$ Ptarmigan and other grouse can draw on the protein of the pectoralis during periods of environmental stress. ${ }^{16}$ Smaller birds with relatively higher protein demands, such as the House Sparrow, will do so overnight. ${ }^{8}$ The different fiber types in the pectoralis appear to be utilized to an equal extent during these periods.

Muscle, like bone, bill or feather, is exquisitely suited to fulfill the demands upon it. Anatomy, physiology, biochemistry and natural history are beautifully intertwined and are, indeed, different facets of the same life processes.

'ANKEY, C.D. 1984. Nutrient reserve dynamics of breeding and moulting brant. Auk 101:361)370.

${ }^{2}$ BAILEY, R.O. 1985 Protein reserve dynamics in postbreeding adult male redheads. Condor 87:23)32.

3DAWSON, W.R., R.L. MARSH and M.E. YACOE 1983. Metabolic adjustments of small passerine birds for migration and cold. Am. J. Physiol. 245:R755-R767.

${ }^{4}$ GEORGE, J.C. 1984. Thermogenesis in birds, pp. 467) 473 in J.R.S. HALES (Ed.), Thermal physiology. Academic Press, N.Y.

${ }^{5}$ GEORGE, J.C. and A.J. BERGER 1966. Avian Myology. Academic Press, N.Y.

6HARTMAN, F.A. 1961. Locomotor 
mechanisms of birds. Smithsonian Misc. Collections 143:1)91.

7JOHNSTON, I.A. 1985. Sustained force development: specializations and variation among the vertebrates. J. Exp. Bio. 115:239-251.

${ }^{8}$ JONES, M. 1980. Nocturnal loss of muscle protein from the House Sparrow (Passer domesticus). J. Zool. Lond. 192:33-39.

${ }^{9}$ MORGAN, D.L., and U. PROSKE 1984. Vertebrate slow muscle: its structure, pattern of innervation, and mechanical properties. Physiol. Rev. 64:103-169.

10NORBERG, U.M. 1985. Flying, gliding and soaring, pp. 129-158 in M. HILDEBRAND, D.M. BRAMBLE, K.F. LIEM, and D.B. WAKE (Eds.), Functional Vertebrate Morphology. Belknap Press of Harvard Univ. Press, Cambridge.

11PERRY, S.V. 1985. Properties of the muscle proteins - a comparative approach. J. Exp. Biol. 115:31-42.
12RAVELING, D.G. 1979. The annual cycle of body composition of Canada Geese with special reference to control of reproduction. Auk 96:234-252.

13ROSSER, B.W.C and J.C. GEORGE 1985. Histochemical characterization and distribution of fiber types in the pectoralis muscle of the Ostrich (Struthio camelus) and Emu (Dromaius novaehollandiae). Acta Zool. 66:191-198.

${ }^{14}$ ROSSER, B.W.C and J.C. GEORGE 1986a. The avian pectoralis: histochemica! characterization and distribution of muscle fiber types. Can. J. Zool. 64:1174-1185.

${ }^{15}$ ROSSER, B.W.C and J.C. GEORGE 1986b. Slow muscle fibers in the pectoralis of the Turkey Vulture (Cathartes aura); an adaptation for soaring flight. Zool. Anz. (in press).

16THOMAS, V.G. and R. POPKO 1981. Fat and protein reserves of wintering and prebreeding Rock Ptarmigan from south Hudson Bay. Can. J. Zool. 59:1205-1211.

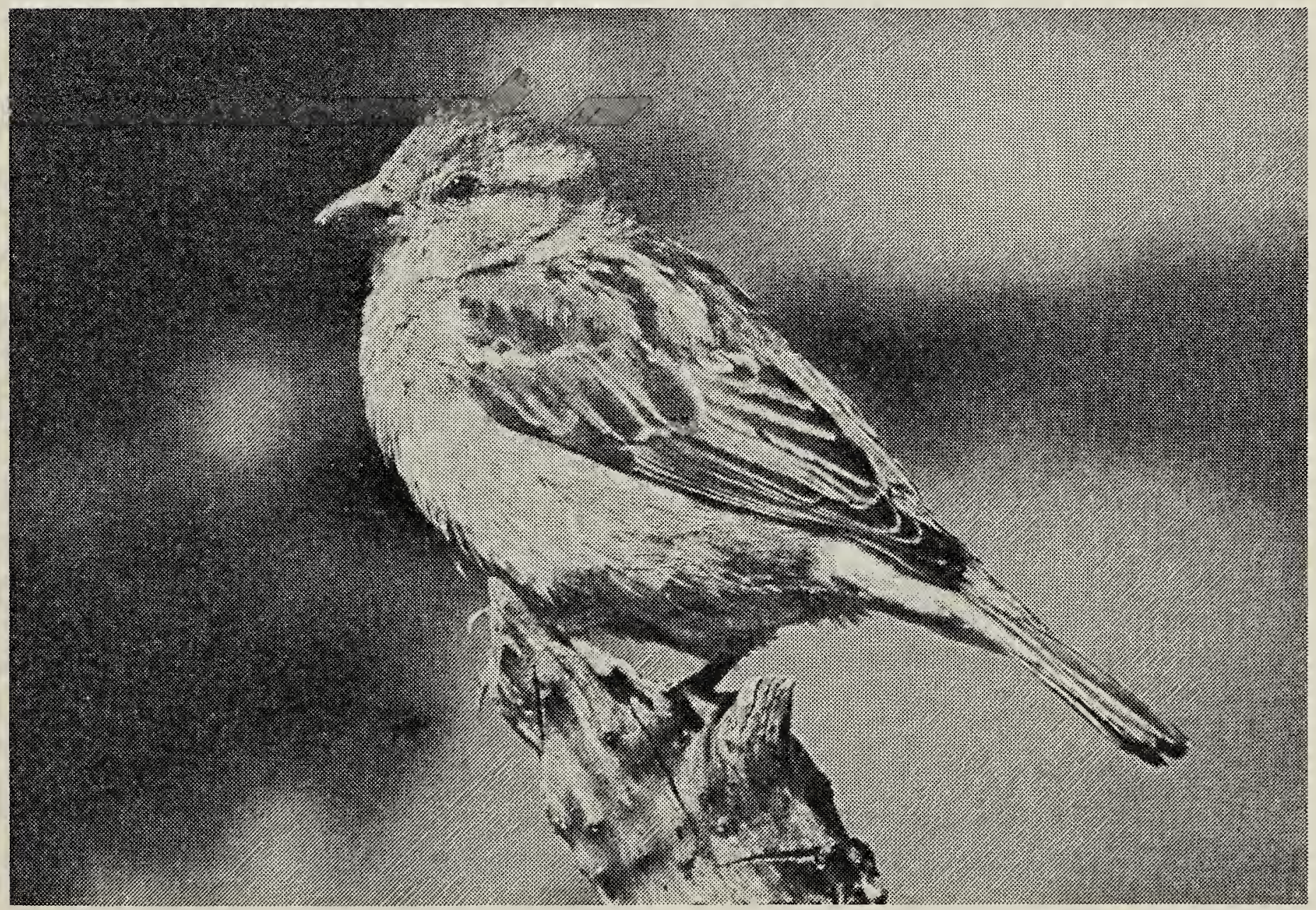

House Sparrow

Fred. W. Lahrman 